Desy Rachmatullah, Desiana Nuriza Putri \& Fiki Herianto, 2021. Karakteristik Biji Kakao

(Theobroma cacao L.) Hasil Fermentasi Dengan Ukuran Wadah Berbeda. Journal Viabel Pertanian. (2021), 15(1) 32-44

\title{
KARAKTERISTIK BIJI KAKAO (Theobroma cacao L.) HASIL FERMENTASI DENGAN UKURAN WADAH BERBEDA
}

\author{
${ }^{1}$ Desy Rachmatullah, ${ }^{2}$ Desiana Nuriza Putri, ${ }^{3}$ Fiki Herianto, ${ }^{4}$ Noor Harini \\ 1,2,4 Jurusan Teknologi Pangan, Fakultas Pertanian Peternakan, \\ Universitas Muhammadiyah Malang, Jl. Raya Tlogomas No. 246, Malang, Jawa Timur \\ 65144, Indonesia \\ ${ }^{3}$ PT. Perkebunan Nusantara XII Kebun Bantaran Afdelling Penataran, Blitar \\ E-mail: ${ }^{1}$ desyrchmtlh29@gmail.com, ${ }^{2}$ desiana@umm.ac.id, \\ fikiheri035@gmail.com ${ }^{4}$ noorhumm@yahoo.co.id
}

\begin{abstract}
The cocoa bean processing process largely determines the quality of dry cocoa beans. The fermentation process has a crucial role in the processing of cocoa beans, namely the formation of the taste and aroma of the cocoa beans produced. This research aims to provide a description of the ideal fermentation and find a fermentation vessel that can be used in small and simple production scales. This research was conducted by carrying out fermentation using two different containers, namely a large wooden box and a small wooden box. The fermentation process lasts for three days (3x24 hours) with daily temperature reversal and monitoring. Fermented cocoa beans are dried by sun drying and mechanical drying (cocoa dryer) for \pm seven days. The results showed that fermentation with large wooden boxes had better effectiveness than small wooden boxes. Cocoa beans produced from the fermentation of small wooden boxes can also ferment well so that small wooden boxes can be used as an alternative for farmers who have low production yields.
\end{abstract}

Keywords: cocoa, container size, fermentation, characteristics, cocoa beans.

\section{PENDAHULUAN}

Kakao (Theobroma cacao L.) telah menjadi salah satu komoditas perkebunan yang mempunyai peran penting dalam perekonomian Indonesia sejak tahun 1930. Pada tahun 2014 Indonesia menduduki peringkat ketiga sebagai negara pengekspor biji kakao terbesar dunia setelah Pantai Gading dan Ghana (International Cocoa Organization, 2015). Namun, biji kakao yang diekspor oleh Indonesia dikenal mempunyai mutu rendah (Mulyono, 2016). Salah satu penyebab rendahnya kualitas biji kakao adalah proses pengolahan biji kakao di Indonesia. Biji kakao Indonesia jarang difermentasi terlebih dahulu, padahal biji kakao hasil fermentasi mempunyai mutu yang lebih baik jika dibandingkan dengan biji kakao yang belum difermentasi (Ariyanti, 2017). Hal itu disebabkan proses fermentasi mempunyai peran penting dalam pembentukan citarasa dan aroma dari biji kakao yang dihasilkan.

Perkebunan kakao di Indonesia dikelola oleh perkebunan negara, perkebunan swasta, dan perkebunan rakyat dengan produksi akhir berupa biji kakao kering. Hasil produksi rakyat sebagian besar berupa biji kering tanpa fermentasi. Proses fermentasi tidak dilakukan oleh petani karena lahan yang dimiliki petani tidak luas dengan hasil produksi yang tidak banyak sedangkan pada proses fermentasi dibutuhkan jumlah biji yang cukup banyak agar suhu fermentasi dapat tercapai, selain itu membutuhkan waktu 
yang cukup lama. Biasanya para petani hanya merendam biji kakao basah untuk membantu menghilangkan pulp kemudian dilanjutkan proses penjemuran. Sehingga biji kakao yang dihasilkan mempunyai mutu kurang baik (Apriyanto, Sutardi, Supriyanto, \& Harmayani, 2017).

Fermentasi biji kakao memegang peranan yang sangat penting pada proses pengolahan biji kakao. Proses fermentasi membantu dalam menghilangkan pulp yang membungkus biji kakao dan membantu dalam mengembangkan prekursor rasa cokelat. Pulp biji kakao mengandung gula dan polisakarida yang kemudian akan difermentasi oleh mikroorganisme. Aktivitas mikroorganisme akan menghasilkan metabolit dan kondisi yang menyebabkan kematian biji dan memulai serangkaian reaksi biokimia di dalam biji kakao yang menghasilkan prekursor rasa cokelat (Ho, Zhao, \& Fleet, 2014). Apabila biji kakao tidak mengalami proses fermentasi, maka cita rasa dan aroma khas kakao tidak terbentuk dan menyebabkan biji akan terasa pahit dan sepat (Pradnyawathi, Wijaya, Sutedja, \& Astiningsih, 2018).

Keberhasilan proses fermentasi ditentukan oleh beberapa faktor, salah satunya adalah wadah fermentasi. Wadah fermentasi yang baik dibuat dari bahan kayu dengan kapasitas sekurang-kurangnya $40 \mathrm{~kg}$. Apabila kapasitas biji kakao tidak mencukupi, maka suhu fermentasi tidak akan tercapai sehingga akan menyebabkan biji kakao berjamur (Ariyanti, 2017). Suhu fermentasi biji kakao dapat mencapai $50^{\circ} \mathrm{C}$ atau bahkan lebih pada sebagian fermentasi. Proses fermentasi dilakukan dengan cara memeram biji kakao basah di dalam wadah tertutup selama 2-8 hari dengan disertai proses pengadukan atau pembalikan (Apriyanto et al., 2017). Lama proses fermentasi ditentukan oleh jenis kakao yang difermentasi. Buah kakao jenis Criollo (kakao mulia / edel) mempunyai waktu fermentasi yang singkat yaitu 2-3 hari, sedangkan buah kakao jenis Forastero (kakao bulk / lindak) membutuhkan waktu 3-7 hari. Lama fermentasi yang dibutuhkan berbeda menyebabkan kedua jenis buah tersebut tidak bisa dicampur ketika proses fermentasi (Amin, 2005).

Penelitian yang dilakukan oleh (Mulyazmi \& Sundari, 2008) menunjukkan hasil bahwa fermentasi yang dilakukan menggunakan fermentor dari bambu memberikan hasil biji kakao yang lebih baik dibandingkan dengan fermentor dari kayu timbalun. Akan tetapi, penelitian yang dilakukan oleh (Rahmi, Zulfahrizal, \& Siregar, 2017) menunjukkan bahwa fermentasi yang dilakukan dengan memakai kotak kayu memberikan hasil yang lebih bagus dibandingkan kotak styrofoam karena pada kotak styrofoam diperoleh biji kakao yang ditumbuhi jamur pada fermentasi hari ke-5. Selain itu, penelitian yang dilakukan oleh (Luh, Novi, Aryani, Yulianti, \& Arda, 2018) menunjukkan hasil bahwa perlakuan kotak kayu 25,5 cm x 25,5 cm x 30,5 cm dengan kuantitas $7,5 \mathrm{~kg}$ yang difermentasikan selama 6 hari menghasilkan karakteristik biji kakao terbaik.

Tujuan dari penelitian ini adalah memberikan gambaran fermentasi biji kakao ideal dan pencarian wadah fermentasi agar bisa digunakan dalam skala produksi kecil dan sederhana, maka dilakukan uji coba perbandingan dengan cara fermentasi biji kakao di wadah kotak kayu berukuran besar dan kecil,

\section{METODE PENELITIAN}

\section{Bahan}

Penelitian ini menggunakan bahan baku berupa biji kakao jenis edel (criollolfine cocoa/kakao mulia) yang diperoleh dari salah satu perkebunan kakao yaitu PT. Perkebunan Nusantara XII Kebun Bantaran Afdelling Penataran, Blitar, Jawa Timur. Biji 
Desy Rachmatullah, Desiana Nuriza Putri \& Fiki Herianto, 2021. Karakteristik Biji Kakao (Theobroma cacao L.) Hasil Fermentasi Dengan Ukuran Wadah Berbeda. Journal Viabel Pertanian. (2021), 15(1) 32-44

kakao yang digunakan adalah biji yang diperoleh dari buah kakao matang yang memiliki usia buah sekitar 5-6 bulan. Buah kakao yang digunakan terdiri dari 3 jenis klon, yaitu DR2, DR38, dan DRC16. Buah kakao yang digunakan adalah buah kakao matang yang mempunyai ciri-ciri warna buah merah dengan garis kekuningan untuk klon DR2, buah berwarna merah gelap untuk klon DR38, berwarna kuning keseluruhan untuk klon DRC16, dan apabila buah diketuk dengan tangan mengeluarkan suara kosong.

Tabel 1. Perbandingan Ciri-ciri Kakao Edel dari Tiga Jenis Klon

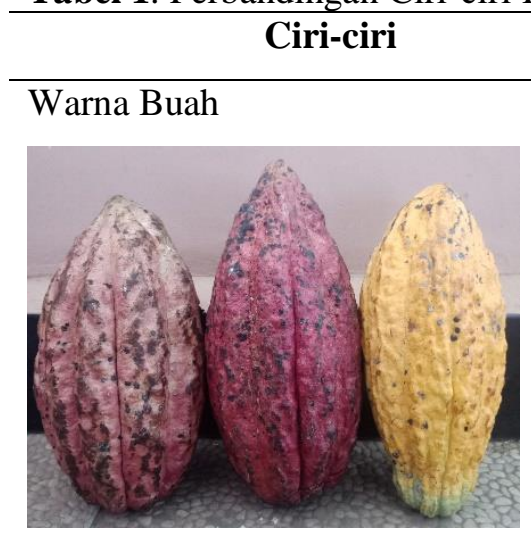

Daun

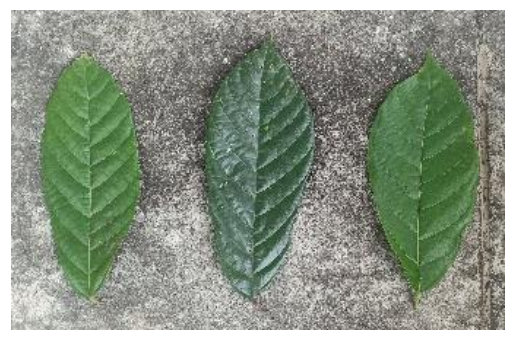

Daun Muda

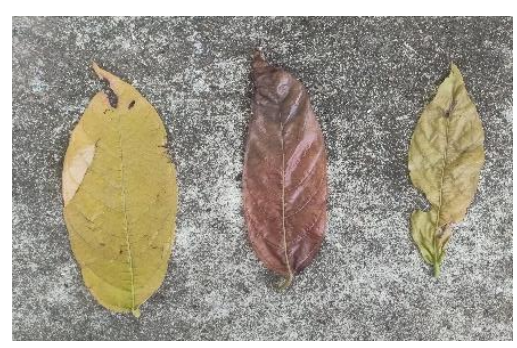

Tangkai Bunga

Kadar Dark Bean

\section{Merah pudar dengan garis \\ kekuningan \\ Merah gelap \\ Kuning \\ oren}

DR $38 \quad$ DRC 16

$\begin{array}{ccc}\text { Hijau } & \text { Hijau gelap } & \text { Hijau } \\ \text { meruncing } & \text { Meruncing } & \text { melebar }\end{array}$




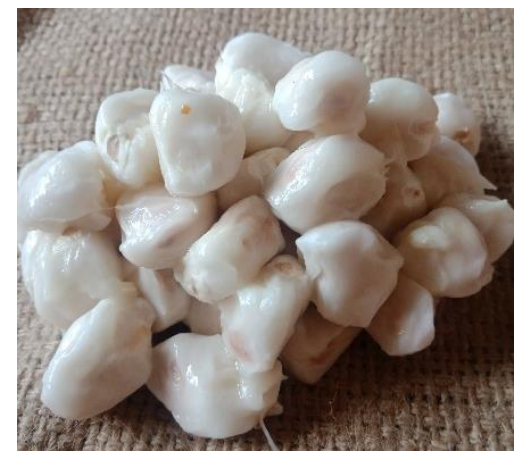

Gambar 1. Biji Kakao Basah

Alat

Alat yang digunakan antara lain kotak kayu besar $(0,7 \mathrm{~m} \times 0,9 \mathrm{~m} \times 1 \mathrm{~m})$, kotak kayu kecil $(20 \mathrm{~cm}$ x $20 \mathrm{~cm} \times 30 \mathrm{~cm})$, karung goni, termometer, alat pengeringan mekanis (cocoa dryer), alat uji kadar air biji kakao (aqua boy merk KPM).

\section{Proses Fermentasi}

Fermentasi biji kakao dilakukan menggunakan kotak kayu selama 3 hari (3 x 24 jam) dengan dilakukan pembalikan dan pemantauan suhu setiap harinya.

\section{Proses Penjemuran dan Pengeringan}

Biji kakao hasil fermentasi kemudian dilakukan penjemuran (sun drying) selama \pm 5 hari dan dilanjutkan pengeringan mekanis menggunakan mesin cocoa dryer dengan suhu berkisar antara $50-60^{\circ} \mathrm{C}$ selama \pm 2 hari agar mencapai target kadar air kurang dari $7,5 \%$.

\section{Uji Kadar Air}

Uji kadar air dilakukan pada biji kakao hasil pengeringan. Prosedur uji kadar air yaitu mengambil beberapa biji kakao kering ( \pm 10 gram) secara acak, kemudian biji kakao dipecah kecil-kecil dan dimasukkan ke dalam cup electrode sampai pada batas, lalu dipres dan ditutup dengan rapat. Cup electrode dipasangkan pada aqua boy kemudian tekan tombol yang berwarna putih, lalu dibaca skala yang ditunjukkan. Skala yang ditunjukkan pada aqua boy kemudian dicocokkan menggunakan tabel konversi yang tersedia. Skala $\mathrm{X}$ menunjukkan skala yang terbaca pada alat, sedangkan skala Y menunjukkan kadar air biji kakao (PT. Perkebunan Nusantara XII, 2000).

\section{Uji Organoleptik}

Uji organoleptik biji kakao dilakukan dengan uji skala hedonik dengan 4 orang panelis tidak terlatih. Parameter yang diujikan pada uji orgaoleptik ini mencakup warna, aroma, tekstur, dan rasa. Panelis diminta untuk memberikan nilai berdasarkan tingkat kesukaannya dengan skor yang digunakan adalah :

$1=$ sangat tidak suka $; 2=$ tidak suka $; 3=\operatorname{agak}$ suka $; 4=$ suka $; 5=$ sangat suka

\section{Analisa Data}

Analisa data dilakukan secara deskriptif untuk menggambarkan perbedaan karakteristik biji kakao yang dihasilkan dari dua ukuran wadah dan menggunakan uji $\mathrm{T}$ 
Desy Rachmatullah, Desiana Nuriza Putri \& Fiki Herianto, 2021. Karakteristik Biji Kakao (Theobroma cacao L.) Hasil Fermentasi Dengan Ukuran Wadah Berbeda. Journal Viabel Pertanian. (2021), 15(1) 32-44

untuk menganalisa pengaruh penggunaan ukuran wadah yang berbeda terhadap karakteristik kakao.

\section{HASIL DAN PEMBAHASAN}

\section{Rendemen}

Efisiensi proses pengolahan dapat diketahui dengan cara perhitungan rendemen. Selain itu, rendemen merupakan salah satu parameter dalam menentukan kualitas biji kakao yang dihasilkan (Arief \& Asnawi, 2011). Nilai rendemen akan semakin kecil seiring dengan meningkatnya komponen bahan yang hilang selama proses pengolahan. Sebaliknya, semakin tinggi nilai rendemen, maka semakin baik pula kualitas kakao yang dihasilkan. Nilai rendemen pada perlakuan kotak kayu besar adalah $34,86 \%$, sedangkan rendemen pada kotak kayu kecil adalah $34,80 \%$. Hal ini menunjukkan bahwa variasi wadah pada proses fermentasi kakao tidak memberikan pengaruh yang signifikan terhadap rendemen biji kakao. Rendemen pada kedua perlakuan ini lebih tinggi dari penelitian (Satryadi, 2013) yang melakukan fermentasi kakao jenis bulk menggunakan kotak kayu dengan ukuran $30 \mathrm{~cm}$ x $30 \mathrm{~cm}$ x $40 \mathrm{~cm}$ yaitu didapatkan rendemen 33,38\%.

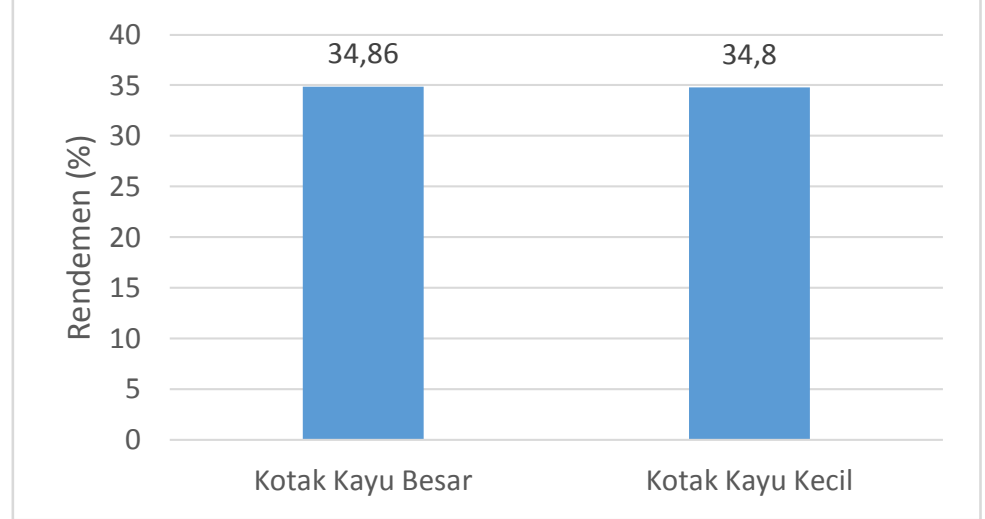

Gambar 2. Rendemen Biji Kakao

Pada proses fermentasi biji kakao, kotak kayu digunakan sebagai wadah fermentasi karena kotak kayu merupakan penghantar panas yang baik. Menurut (Rahmi et al., 2017), kayu mempunyai nilai konduktivitas lebih besar dibandingkan dengan styrofoam. Bahan yang mempunyai nilai konduktivitas termal yang besar termasuk ke dalam kelompok penghantar panas yang baik. Sebaliknya, bahan yang mempunyai nilai konduktivitas termal yang kecil termasuk ke dalam kelompok bahan penghantar panas yang buruk. Penggunaan karung goni sebagai penutup wadah selama fermentasi biji kakao bertujuan untuk mencegah panas keluar pada saat fermentasi dan uap air yang dihasilkan dari proses fermentasi dapat diserap oleh karung goni sehingga uap air yang sudah keluar tidak kembali lagi ke biji kakao.

\section{Suhu Fermentasi Biji Kakao}

Fermentasi biji kakao oleh mikroorganisme terjadi secara alami dengan bantuan oksigen dari udara. Proses fermentasi dapat berlangsung dengan baik apabila oksigen tersedia dalam jumlah yang cukup dan akan menimbulkan panas akibat peningkatan suhu yang merupakan hasil oksidasi senyawa gula di dalam pulp. Beberapa faktor yang mempengaruhi perubahan suhu selama proses fermentasi antara lain proses pengadukan 
Desy Rachmatullah, Desiana Nuriza Putri \& Fiki Herianto, 2021. Karakteristik Biji Kakao (Theobroma cacao L.) Hasil Fermentasi Dengan Ukuran Wadah Berbeda.

Journal Viabel Pertanian. (2021), 15(1) 32-44

(pembalikan), aerasi, iklim, suhu lingkungan, tingkat kemasakan buah, wadah, dan kapasitas fermentasi (Ariyanti, 2017). Lama fermentasi juga mempengaruhi keberhasilan proses fermentasi karena fermentasi yang terlalu singkat dapat menyebabkan biji kakao yang dihasilkan bermutu rendah yaitu biji slaty (biji yang jika dibelah tidak berongga atau padat), sedangkan fermentasi yang terlalu lama akan mengakibatkan visual biji berwarna hitam.

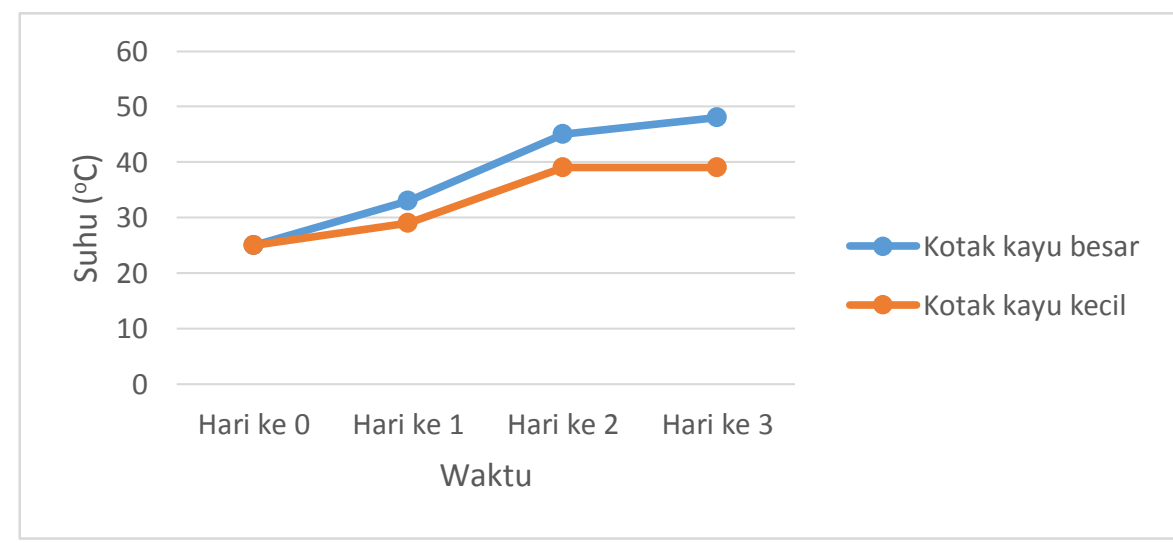

Gambar 3. Perubahan Suhu selama Proses Fermentasi

Aktivitas yang terjadi pada proses fermentasi biji kakao ditunjukkan melalui perubahan suhu fermentasi mulai dari awal hingga akhir masa fermentasi. Suhu awal fermentasi $\pm 25^{\circ} \mathrm{C}$ pada kedua perlakuan. Kemudian, kedua perlakuan mengalami peningkatan suhu dari awal masa fermentasi (Gambar 3). Menurut (Apriyanto et al., 2017), peningkatan suhu pada proses fermentasi biji kakao disebabkan oleh reaksi enzimatik yang terjadi di dalam biji kakao. Aktivitas mikroba pelaku fermentasi akan menghasilkan alkohol, asam, dan melepaskan panas akibat dari reaksi eksotermik. Kedua perlakuan mengalami peningkatan suhu selama proses fermentasi, akan tetapi perlakuan yang mampu mencapai suhu optimum adalah perlakuan kotak kayu besar yaitu $48^{\circ} \mathrm{C}$ pada hari ketiga. Capaian suhu pada perlakuan kotak kayu besar ini lebih tinggi dari penelitian (Rahmi et al., 2017) yang menggunakan wadah kotak styrofoam yaitu $46^{\circ} \mathrm{C}$ pada hari ketiga. Sedangkan perlakuan kotak kayu kecil belum mencapai suhu optimum fermentasi. Suhu optimal yang diperlukan untuk fermentasi biji kakao agar mendapatkan hasil dengan mutu baik adalah $44-48^{\circ} \mathrm{C}$ (Luh et al., 2018). Tetapi tidak menutup kemungkinan suhu fermentasi akan meningkat hingga $50^{\circ} \mathrm{C}$ atau bahkan lebih. Karena peningkatan suhu pada proses fermentasi terjadi akibat reaksi perombakan alkohol menjadi asam laktat dan asam asetat. Reaksi perombakan tersebut merupakan reaksi eksotermis yang mengeluarkan energi panas (Amin, 2005). 
Desy Rachmatullah, Desiana Nuriza Putri \& Fiki Herianto, 2021. Karakteristik Biji Kakao (Theobroma cacao L.) Hasil Fermentasi Dengan Ukuran Wadah Berbeda. Journal Viabel Pertanian. (2021), 15(1) 32-44

Tabel 2. Perbandingan Proses Fermentasi pada Kotak Kayu Besar dan Kotak Kayu Kecil

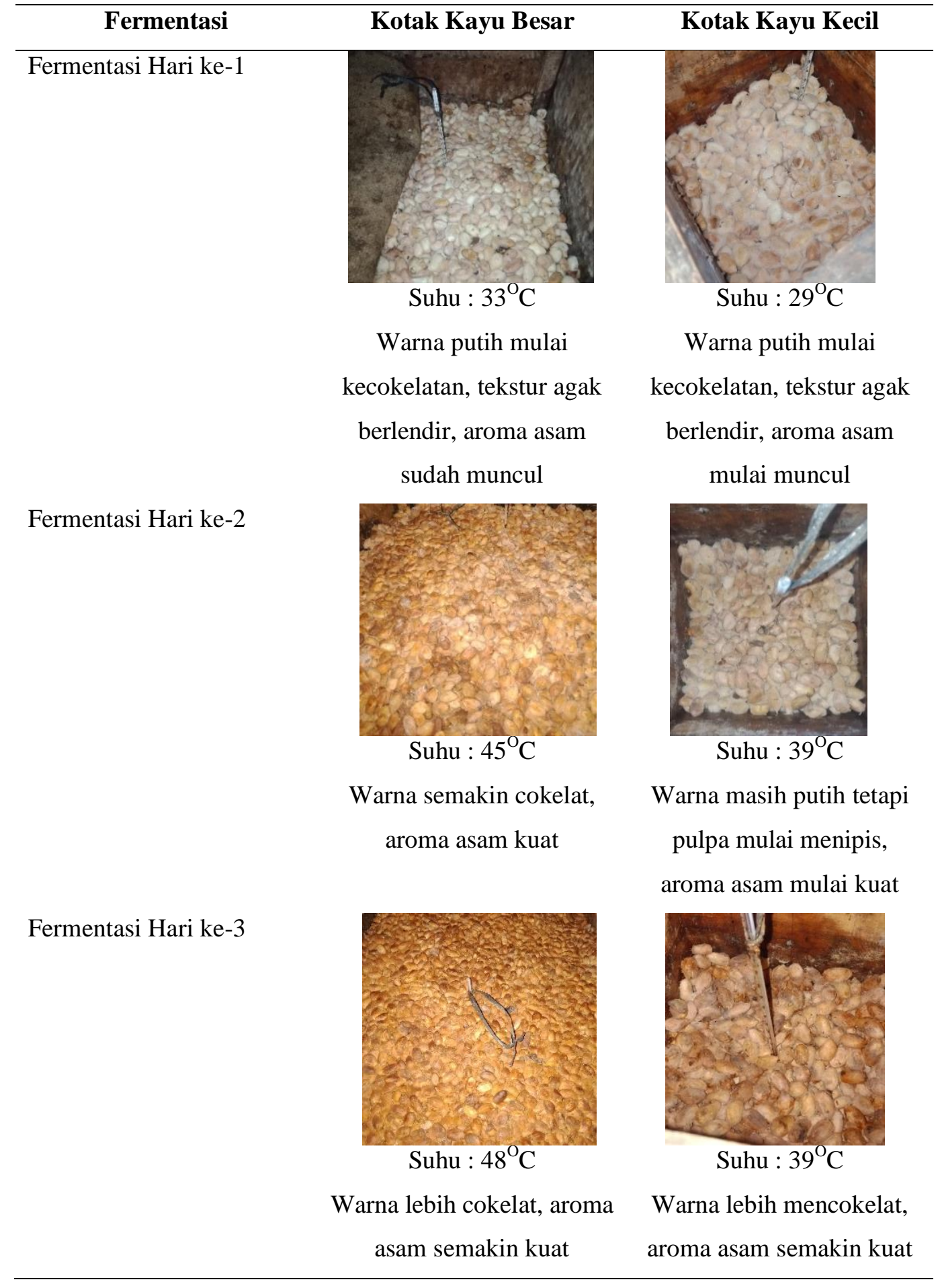




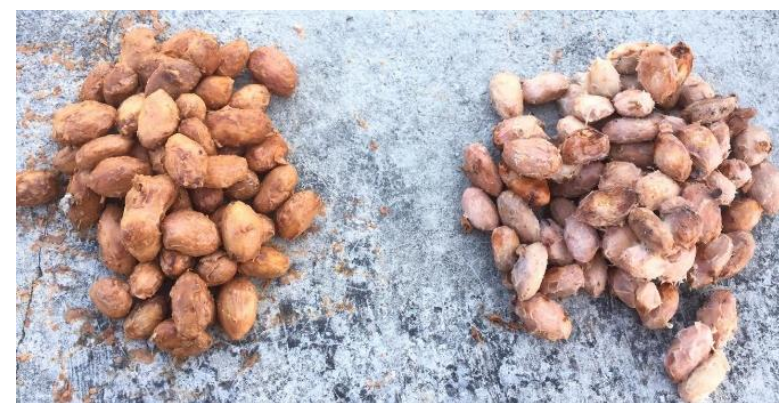

Gambar 4. Hasil Fermentasi pada Kotak Kayu Besar dan Kotak Kayu Kecil selama 3 hari

\section{Pengeringan Biji Kakao}

Tabel 3. Perbandingan Proses Pengeringan pada Kotak Kayu Besar dan Kotak Kayu Kecil

\begin{tabular}{|c|c|c|}
\hline Pengeringan hari ke - & Kotak Kayu Besar & Kotak Kayu Kecil \\
\hline Pengeringan hari ke-1 & & \\
\hline Pengeringan hari ke-2 & 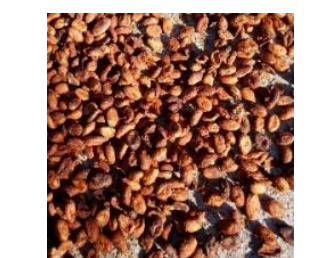 & 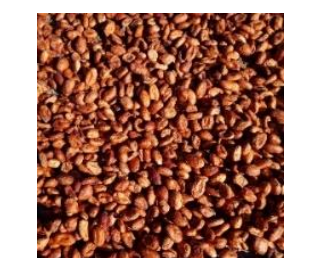 \\
\hline Pengeringan hari ke-3 & & \\
\hline Pengeringan hari ke- 4 & & \\
\hline Pengeringan hari ke-5 & & \\
\hline
\end{tabular}



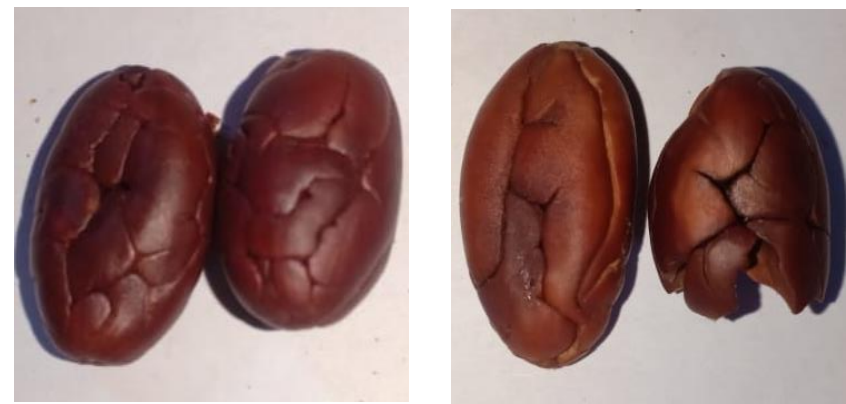

Gambar 5. Hasil Pengeringan Biji Kakao selama \pm 7 hari (Kotak Kayu Besar dan Kotak Kayu Kecil)

Penampakan warna biji kakao selama proses penjemuran menunjukkan warna yang semakin gelap pada kedua perlakuan. Akan tetapi warna biji kakao pada perlakuan kotak kayu besar mengarah ke warna cokelat tua, sedangkan perlakuan kotak kayu kecil mengarah ke warna cokelat muda. Perbedaan warna tersebut berhubungan dengan keberhasilan proses fermentasi sebelumnya. Perlakuan kotak kayu besar dapat terfermentasi lebih optimal dibandingkan kotak kayu kecil karena pada kotak kayu besar mampu mencapai suhu optimum fermentasi. Penelitian yang telah dilakukan (Marpaung \& Putri, 2019) juga menunjukkan biji kakao kering berwarna cokelat sampai cokelat kehitaman. Meskipun warna yang dihasilkan tidak sama, kedua perlakuan dapat terfermentasi dengan baik ditandai dengan biji kakao yang berwarna cokelat. Biji kakao yang dapat difermentasi dengan baik ditunjukkan dengan warna keping biji cokelat dominan, mempunyai tekstur agak remah atau mudah pecah, cita rasa pahit dan sepat tidak dominan. Tahapan penting dalam pengolahan biji kakao terdiri dari proses fermentasi dan pengeringan. Karena kedua tahapan tersebut berperan dalam pembentukan rasa yang merupakan parameter penting pada pengolahan cokelat. Pada proses pengeringan biji kakao, pembentukan rasa dan proses pencoklatan biji masih berlanjut, sedangkan rasa sepat, rasa pahit dan keasaman berkurang (Rodriguez-Campos et al., 2012).

\section{Kadar Air}

Proses fermentasi dapat menyebabkan penurunan kadar air pada biji kakao. Perubahan kadar air tersebut disebabkan oleh proses fermentasi yang mengakibatkan aktivitas mikroba dan enzim meningkat menjadi lebih aktif. Reaksi tersebut akan menghasilkan panas sehingga pulp akan hancur dan menjadi cair sehingga dapat mengakibatkan jaringan kompleks pada biji kakao terurai menjadi senyawa organik lebih sederhana (Marwati, Suprapto, \& Yulianti, 2013). Hancurnya pulp pada biji kakao dapat menyebabkan pori-pori pada biji terbuka dan memudahkan air bebas keluar sehingga proses pengeringan menjadi lebih mudah. Selain itu, air bebas dalam biji kakao dapat keluar dengan mudah dikarenakan sifat semipermeabilitas dinding sel rusak sebagai akibat dari proses fermentasi yang juga menyebabkan kematian biji (Ariyanti, 2017). Metode penjemuran (sun drying) selama \pm 5 hari yang kemudian dilanjutkan dengan pengeringan menggunakan cacao dryer dapat menurunkan kadar air pada kedua perlakuan hingga mencapai standar. 
Desy Rachmatullah, Desiana Nuriza Putri \& Fiki Herianto, 2021. Karakteristik Biji Kakao

(Theobroma cacao L.) Hasil Fermentasi Dengan Ukuran Wadah Berbeda.

Journal Viabel Pertanian. (2021), 15(1) 32-44

Tabel 4. Kadar Air pada Kedua Perlakuan

\begin{tabular}{lc}
\hline Perlakuan & Kadar Air (\%) \\
\hline Kotak Kayu Besar & 7,0 \\
Kotak Kayu Kecil & 7,0 \\
\hline
\end{tabular}

Nilai rata-rata kadar air pada kedua perlakuan sama (Tabel 4). Hal ini menunjukkan bahwa perbedaan wadah fermentasi kakao tidak memberikan pengaruh yang signifikan terhadap kadar air biji kakao. Berdasarkan SNI 2323:2008 kadar air biji kakao kering maksimum 7\%. Kadar air pada kedua perlakuan telah sesuai dengan standar mutu biji kakao kering. Kadar air yang dicapai ini lebih rendah dari penelitian (Ariyanti, 2017) yang hanya menggunakan pengeringan dengan cara dijemur (sun drying) yaitu didapatkan kadar air $\pm 8 \%$. Menurut (Amin, 2005), biji kakao hasil fermentasi mempunyai kadar air $\pm 55 \%$ dan harus segera dilakukan pengeringan sampai kadar air akhir biji kakao mencapai maksimum 7\%.

Biji kakao kering dengan kadar air maksimum $7 \%$ dihasilkan dari proses pengeringan yang baik dan optimal. Pengeringan yang terlalu lama dapat mengakibatkan kadar air biji kakao jauh di bawah 7\%. Jika kadar air biji kakao kurang dari 5\%, maka kulit biji kakao akan mudah pecah atau rapuh sehingga biji harus dipisahkan karena kadar biji pecah yang tinggi. Begitupun sebaliknya, jika proses pengeringan terlalu cepat, maka biji kakao belum mencapai kadar air keseimbangan (7\%) dan mengakibatkan biji kakao rentan terhadap serangan jamur dan bakteri yang dapat menurunkan mutu biji kakao.

\section{Uji Organoleptik}

Uji organoleptik biji kakao dilakukan menggunakan metode uji skala hedonik dengan parameter uji yang terdiri dari warna, aroma, tekstur, dan rasa. Skor uji hedonik yang diberikan oleh keempat panelis menunjukkan bahwa variasi ukuran wadah fermentasi tidak menunjukkan pengaruh yang signifikan terhadap warna biji kakao kering. Biji kakao yang dihasilkan berwarna cokelat dengan tingkatan warna cokelat yang berbeda, dimana perlakuan kotak kayu besar menghasilkan warna cokelat tua dan kotak kayu kecil menghasilkan warna cokelat yang lebih terang. Penelitian yang dilakukan oleh (Marpaung \& Putri, 2019) menunjukkan hasil bahwa biji kakao kering yang dihasilkan berwarna cokelat hingga cokelat kehitaman. Proses fermentasi dan pengeringan menyebabkan perubahan warna pada biji kakao kering. Biji kakao yang terfermentasi dengan baik akan menyebabkan kandungan polifenol teroksidasi sehingga muncul warna cokelat. Selain itu warna cokelat pada biji kakao terjadi karena reaksi maillard pada saat pengeringan biji kakao. Reaksi maillard mengakibatkan reaksi non enzimatis yaitu reaksi antara senyawa hidrokarbon (gula pereduksi) dengan gugus amin bebas dan asam amino atau protein. Reaksi tersebut yang menyebabkan perubahan warna pada biji kakao (Marpaung \& Putri, 2019). 
Desy Rachmatullah, Desiana Nuriza Putri \& Fiki Herianto, 2021. Karakteristik Biji Kakao (Theobroma cacao L.) Hasil Fermentasi Dengan Ukuran Wadah Berbeda. Journal Viabel Pertanian. (2021), 15(1) 32-44

Tabel 5. Hasil Uji Organoleptik

\begin{tabular}{cccccc}
\hline \multirow{2}{*}{ Perlakuan } & \multirow{2}{*}{ Panelis } & Warna & \multicolumn{2}{c}{ Sifat Organoleptik } \\
& Aroma & Tekstur & Rasa \\
\hline \multirow{3}{*}{ Kotak Kayu } & P I & 5 & 4 & 4 & 5 \\
Besar & P II & 4 & 3 & 5 & 4 \\
& P III & 3 & 4 & 3 & 3 \\
& P IV & 4 & 5 & 3 & 4 \\
Kotak Kayu & P I & 2 & 3 & 4 & 3 \\
Kecil & P II & 4 & 2 & 5 & 4 \\
& P III & 5 & 3 & 3 & 5 \\
& P IV & 5 & 3 & 5 & 4 \\
\hline
\end{tabular}

Skor uji hedonik yang diberikan oleh keempat panelis memperlihatkan bahwa perbedaan ukuran wadah fermentasi memberikan pengaruh yang signifikan terhadap aroma biji kakao kering. Biji kakao perlakuan kotak kayu besar mempunyai aroma yang lebih kuat dibandingkan dengan perlakuan kotak kayu kecil. Penelitian yang dilakukan oleh (Marpaung \& Putri, 2019) menunjukkan bahwa aroma biji kakao yang dihasilkan disukai oleh panelis. Aroma pada biji kakao dipengaruhi oleh proses fermentasi dan pengeringan. Komponen aroma biji kakao terdiri dari senyawa mudah menguap yang terbentuk dari reaksi gugus amina dan karboksil. Kedua senyawa tersebut merupakan hasil penguraian peptida dan karbohidrat selama fermentasi. Senyawa fenol juga dapat memberikan aroma pada biji kakao. Senyawa pirazin dan benzene merupakan senyawa golongan aromatik yang terbentuk akibat proses pengeringan pada biji kakao (Marpaung \& Putri, 2019).

Ukuran wadah fermentasi tidak berpengaruh signifikan terhadap tekstur biji kakao kering. Tekstur biji kakao dipengaruhi oleh proses fermentasi dan pengeringan. Proses fermentasi menyebabkan tekstur biji menjadi berongga karena selama proses fermentasi berlangsung terjadi perombakan senyawa-senyawa protein, sukrosa, fenol, dan senyawa lain oleh enzim-enzim yang terdapat pada biji kakao. Biji kakao yang terfermentasi sempurna bertekstur agak remah atau mudah dipecah. Selain itu, proses pengeringan juga mempengaruhi tekstur biji kakao. Proses pengeringan yang optimal akan menghasilkan biji kakao yang renyah. Akan tetapi pengeringan yang tidak merata akan menyebabkan biji kakao ada yang renyah dan ada yang tidak.

Rasa biji kakao kering tidak dipengaruhi ukuran wadah fermentasi. Beberapa faktor yang dapat mengakibatkan rendahnya mutu biji kakao diantaranya proses fermentasi yang berjalan kurang optimal, pengeringan biji yang kurang kering, ukuran biji tidak sama, cita rasa sangat bermacam-macam, dan ketidakkonsistenan lainnya. Hasil penelitian yang dilakukan oleh (Marpaung \& Putri, 2019) menunjukkan bahwa cita rasa cokelat yang dihasilkan disukai oleh panelis. Cita rasa pada biji kakao dipengaruhi oleh proses fermentasi dan pengeringan. Perombakan senyawa protein, gula, dan polifenol oleh enzim yang membentuk senyawa calon rasa terjadi pada proses fermentasi. Sehingga jika fermentasi dapat berjalan sempurna, maka senyawa-senyawa tersebut semakin banyak yang terurai. Selain itu pada proses pengeringan senyawa-senyawa yang membentuk cita rasa saling bereaksi melalui reaksi maillard yang selanjutnya menghasilkan komponen-komponen mudah menguap dan mempunyai aroma khas cokelat seperti golongan furan, ester, tiazol, alkohol, pirazin, dan perol (Marpaung \& Putri, 2019). 


\section{KESIMPULAN}

Proses fermentasi dan pengeringan merupakan faktor-faktor yang menentukan kualitas biji kakao kering yang dihasilkan. Karena proses fermentasi dan pengeringan berperan penting dalam pembentukan cita rasa dan aroma biji kakao. Fermentasi dengan kotak kayu besar memiliki efektifitas lebih baik dibandingkan kotak kayu kecil. Hal ini dikarenakan perlakuan kotak kayu besar dapat mencapai suhu optimal fermentasi dan warna biji kakao yang dihasilkan lebih optimal. Biji kakao pada perlakuan kotak kayu kecil juga dapat terfermentasi dengan baik sehingga kotak kayu kecil dapat dijadikan alternatif untuk petani agar dapat melakukan fermentasi biji kakao untuk memperoleh biji kakao dengan mutu yang lebih baik dibandingkan tanpa fermentasi.

\section{DAFTAR PUSTAKA}

Amin, S. (2005). Teknologi Pasca Panen Kakao untuk Masyarakat Perkakaoan Indonesia. Jakarta: Badan Pengkajian dan Penerapan Teknologi Press.

Apriyanto, M., Sutardi, S., Supriyanto, S., \& Harmayani, E. (2017). Fermentasi Biji Kakao Kering Menggunakan Saccharomyces cerevisiae, Lactobacillus lactis, dan Acetobacter aceti. Agritech.

Arief, R. W., \& Asnawi, R. (2011). Karakterisasi Sifat Fisik dan Kimia Beberapa Jenis Biji Kakao Lindak di Lampung. Journal of Industrial and Beverage Crops, 2(3), 325-330.

Ariyanti, M. (2017). Karakteristik Mutu Biji Kakao (Theobroma cacao L) Dengan Perlakuan Waktu Fermentasi Berdasar SNI 2323-2008. (Quality Characteristics Of CocoaBeans (Theobroma cacao L) WithTime FermentationTreatment Based on ISO 2323-2008). Jurnal Industri Hasil Perkebunan, 12(1), 34-42.

Ho, V. T. T., Zhao, J., \& Fleet, G. (2014). Yeasts are essential for cocoa bean fermentation. International Journal of Food Microbiology, 174, 72-87.

International Cocoa Organization. (2015). ICCO Bulletin of Cocoa Statistic.

Luh, N., Novi, P., Aryani, A., Yulianti, N. L., \& Arda, G. (2018). Karakteristik Biji Kakao Hasil Fermentasi Kapasitas Kecil dengan Jenis Wadah dan Lama Fermentasi yang Berbeda Characteristics of Cocoa Beans on Small Capacity Fermentation Results Based on Different Types of Containers and Different Fermentation Lengths A. 6, 17-24.

Marpaung, R., \& Putri, S. N. (2019). Karakteristik Mutu Organoleptik Olahan Coklat Dengan Lama Fermentasi yang Berbeda Pada Biji Kakao Lindak (Theobroma cacao L.)". Jurnal Media Pertanian, 4(2), 64.

Marwati, Suprapto, H., \& Yulianti. (2013). Pengaruh Tingkat Kematangan terhadap Mutu Biji Kakao (Theobroma cacao L.) yang Dihasilkan Petani Kakao di Teluk Kedondong Bayur Samarinda. Jurnal Teknologi Pertanian, 8(1), 6-11.

Mulyazmi, \& Sundari, E. (2008). Mempelajari Pengaruh Jenis Material Fermentor dan Kondisi Fermentasi terhadap Mutu Biji Kakao. Jurnal Teknos-2k, 8(1), 48-54.

Mulyono, D. (2016). Harmonisasi Kebijakan Hulu-Hilir dalam Pengembangan Budidaya dan Industri Pengolahan Kakao Nasional. Jurnal Ekonomi \& Kebijakan Publik, $7(2), 185-200$. 
Desy Rachmatullah, Desiana Nuriza Putri \& Fiki Herianto, 2021. Karakteristik Biji Kakao (Theobroma cacao L.) Hasil Fermentasi Dengan Ukuran Wadah Berbeda. Journal Viabel Pertanian. (2021), 15(1) 32-44

Pradnyawathi, N. L. M., Wijaya, I. K. A., Sutedja, I. N., \& Astiningsih, A. A. M. (2018). Kajian Beberapa Cara Fermentasi yang Dilakukan oleh Petani terhadap Mutu Biji Kakao ( Theobroma cacao L .). Agrotrop, 8(2), 189-196.

PT. Perkebunan Nusantara XII. (2000). Pedoman Pengolahan Budidaya Kakao Edel. Surabaya.

Rahmi, F., Zulfahrizal, Z., \& Siregar, K. (2017). Analisis Pindah Panas pada Ruang Fermentasi Biji Kakao (Theobroma cacao L) dengan Menggunakan Kotak Kayu dan Styrofoam. Rona Teknik Pertanian, 10(1), 34-45.

Rodriguez-Campos, J., Escalona-Buendía, H. B., Contreras-Ramos, S. M., Orozco-Avila, I., Jaramillo-Flores, E., \& Lugo-Cervantes, E. (2012). Effect of fermentation time and drying temperature on volatile compounds in cocoa. Food Chemistry, 132(1), 277-288.

Satryadi. (2013). Mempelajari Sifat Fisik dan Fisiko Kimia Buah dan Biji Kakao Hasil Peremajaan Tanaman Kakao (Teknik Sambung Samping) di Kabupaten Luwu Utara. 